Mehmet Akif Ersoy Üniversitesi Fen Bilimleri Enstitüsü Dergisi 11(1): 12-21 (2020)

The Journal of Graduate School of Natural and Applied Sciences of Mehmet Akif Ersoy University 11(1): 12-21 (2020)

Araştırma Makalesi / Research Paper

\title{
Dallı Servi ve Piramit Servi'nin Morfolojik Fidan Özellikleri
}

\author{
Murat USLU (iD), Nebi BíLiR iD 1* \\ ${ }^{1}$ Isparta Uygulamalı Bilimler Üniversitesi, Orman Fakültesi, Isparta \\ Geliş Tarihi (Received): 29.01.2020, Kabul Tarihi (Accepted): 10.03.2020 \\ $\square$ Sorumlu Yazar (Corresponding author ${ }^{*}$ ): nebibilir@isparta.edu.tr \\ (C) +902462146476 且 +902462146599
}

\begin{abstract}
öz
1+0 yaşı çıplak köklü Dallı ve Piramit servi de fidan morfolojisi ve kalitesinin araştıııldığı bu çalışmada, ortalama fidan boyu ve kök boğazı çapı değerleri sırasıyla Dallı servide (Cupressus sempervirens L. var. horizontalis) $84 \mathrm{~cm}$ ve 8,7 $\mathrm{mm}$; Piramit servide (Cupressus sempervirens L. var. piramidalis) $78,9 \mathrm{~cm}$ ve $8,2 \mathrm{~mm}$ bulunmuştur. Fidan boyu ve kök boğazı çapı bakımından Dallı servi Piramit serviye göre daha yüksek performans göstermiştir. Uygulanan varyans analizi sonucunda fidan boyu ve kök boğazı çapı bakımından taksonlar arası anlamlı $(p \leq 0.05)$ fark ortaya çıkmıştır. Korelasyon analizi sonucunda her iki taksonda da; fidan boyu ile kök boğazı arasındaki istatistiksel bakımdan anlamlı $(p \leq 0.05)$ pozitif ilişkiler $(r=0.299, r=0.255$ ve $r=0.308)$ belirlenmiştir. Değerlendirmeler sonucunda her iki taksonda da boy ve çap bakımından fidanların tamamının Türk Standartları Enstitüsü'nün kalite sınıflarına göre kaliteli fidan sınıfında yer aldığı ortaya çıkmıştır. Çalışma kapsamında taksonlara göre oluşturulan yeni kalite sınıflarında; Dallı servi de en yüksek dikime elverişsiz fidanların fidan boyu ve kök boğazı çapının birlikte değerlendirildiği kalite sınıflarında (\%36,7 ve \%26,7) olduğu belirlenmiştir. Uygulanan ayırma analizi sonucunda bu yeni kalite sınıflarının, \%82- \%98 arasında değişen oranlarda başarılı olduğu görülmektedir. Piramit servide ise oluşturulan yeni kalite sınıflarına göre, dikime elverişsiz fidanların fidan boyu ve kök boğazı çapının birlikte değerlendirildiği kalite sınıflarında (\% 42,7 ve \%52,7) yer aldığı anlaşıımıştır. Ayırma analizi sonucunda, yeni kalite sınıflarının, \%80,0- \%96,7 arasında değişen oranlarda başarılı olduğu ortaya çıkmıştır.
\end{abstract}

Anahtar Kelimeler: Cupresus sempervirens, fidan, kök boğazı çapı, morfoloji

\section{Morphological Seedling Characteristics in Mediterranean and Pyramidal Cypresses}

\begin{abstract}
Averages of seedling height and root-collar diameter were $84 \mathrm{~cm}$ and $8.7 \mathrm{~mm}$ in Mediterranean cypress (Cupressus sempervirens L. var. horizontalis), while they were $78.9 \mathrm{~cm}$ and $8.2 \mathrm{~mm}$ in Pyramidal cypress (Cupressus sempervirens $\mathrm{L}$. var. piramidalis) in this study carried out to contribute morphology and quality on 1+0 bare root seedlings of the species. Mediterranean cypress showed higher growth performances than Pyramidal cypress for the both characteristics. Significant differences $(p \leq 0.05)$ were found between taxa for height and diameter based on results of variance analysis. Results of correlation analysis showed positive and significant $(p \leq 0.05)$ relations $(r=0.299, r=0.255$ and $r=0.308$ ) between seedling height and root-collar diameter in both taxa. All of the seedlings of both taxa were in quality level according to classes of Turkish Standard Institute for both seedling height and root-collar diameter. Highest unsuitable rates of seedlings were $36.7 \%$ and $26.7 \%$ for combination of height and diameter in Mediterranean cypress according to obtained new seedling quality classes in the study. Suitability of the new quality classes were between $82 \%$ and $98 \%$ for the characteristics in the taxa based on results of Discriminant analysis. Seedlings had the highest unsuitable rate (42.7\% and $52.7 \%$ ) in combination of height and diameter of new seedling quality classes


in Pyramidal cypress. The successful rate of new quality classes ranged from $80.0 \%$ to $96.7 \%$ according to results of Discriminant analysis.

Keywords: Cupresus sempervirens, seedling, root-collar diameter, morphology

\section{Giriş}

İnsan nüfusu artışına paralel olarak orman ve orman ürünlerine olarak çeşitlilik ve miktarda artmaktadır. Bu durum mevcut orman alanlarından en yüksek ve sürekliliği bozmayacak şekilde yararlanma ile verimsiz orman alanlarının verimli hale getirilmesinde; sadece asli değil tali bitki türlerden faydalanmayı da ön plana çıkarmaktadır. Bu potansiyel tali türlerden biri de Türkiye'de doğal olarak yayılış gösteren tek Servi türü olan Akdeniz servisi ya da Adi servi (Cupressus sempervirens L.) olarak adlandırılan türün, Dallı servi (Cupressus sempervirens L. var. horizontalis (Mill.) Gord.) ve Piramit/Ehrami servi (Cupressus sempervirens L. var. piramidalis Nym.) olmak üzere iki varyetesidir (Anşin ve Özkan, 1993). Servi sadece ekonomik değere sahip bir orman ağacı değil aynı zamanda sosyo-kültürel ve tarihsel bakımdan da insan hayatında önemli bir değer taşımaktadır; bu taksonlar kıymetli odunu yanında, endamlı görüntüsü ve muhteşem yeşil bir alevi andıran tepe yapısının rolü ile geçmişten günümüze yakın bir ilgiye konu olmuştur. Eski Mısır, Lübnan ve İran'da yaşayan toplumların Sedir, Servi ve Ardıç gibi ağaç türlerini Kutsal saymışlardır. Yine Yunan Mitolojisinde Akdeniz Yöresi'nin önemli ağaç türlerinden sayılan Servinin, Apollon'un aşık olduğu Girit'li Cupaerrisos adında bir delikanlının Tanrı Zeus tarafından ağaç haline getirilmiş görüntüsü olduğu belirtilmiştir (Kayacık, 1966); Servi ülkemizde mezarlık ağacı olarak bilinir ve üzüntü simgesi olarak değerlendirilir (Anşin ve Özkan, 1993). Bunlarla birlikte, Neyişçi (1996) laboratuvar koşullarında belirlenen ateş alma gecikim süreleri yanında türün sahip olduğu diğer özelliklere (yaşlandıkça taç içindeki yaş/kuru madde oranının fazlaca değişmemesi gibi) dayanarak servinin etkin bir yangın önleyici olarak kullanılabileceğini ileri sürmektedir. Tür Orman Genel Müdürlüğü tarafından Yanan Orman Alanlarının Rehabilitasyonu ve Yangına Dirençli Ormanlar Tesisi Projesinin de (YARDOP) türlerinden biridir.

Servi taksonlarının ağaçlandırma çalışmalarındaki bu potansiyel avantajları ve gerekse ülke genel alanının \%28,6'sını kaplayan 22,3 milyon hektar büyüklüğündeki orman alanımızın \%43'nün (9,6 milyon hektar) bozuk vasıfta (Anonim, 2015) yani ağaçlandırma uygulamalarına konudur. Bu ağaçlandırma uygulamalarının temel aşaması da ağaçlandırma sahasına uygun kaliteli fidan yetiştirilmesidir. Ancak çalışmaya konu taksonların sınırlı yayılışına bağlı olarak fidanlık tekniği üzerinde sınırlı sa- yıda araştırma gerçekleştirilmiştir. Bu bağlamda çalışmamızda, Türkiye'de doğal olarak yayılış gösteren tek Servi türü olan Akdeniz servisinin, Dallı servi ve Piramit servi varyetelerinin Antalya Orman Fidanlığı'nda yetiştirilen 1+0 yaşlı çıplak köklü fidanlarında, fidan boyu ve kök boğazı çapı bağlamında morfolojik özellikleri ile fidan kalitesi araştırılarak türün fidanlık tekniği, ağaçlandırma ve diğer ormancılık faaliyetlerine katkı sağlanması amaçlanmıştır.

\section{MATERYAL VE YÖNTEM}

\section{Antalya Orman Fidanlığı}

Çalışmanın gerçekleştirildiği Antalya Orman Fidanlığı, $30^{\circ} 31^{\prime}$ doğu boylamı ile $36^{\circ} 36^{\prime}$ Kuzey enleminde yer almakta olup, Antalya ili Kepez ilçesi Zeytinköy Kır Mevkii'nde kuruluş göstermektedir ve denizden yüksekliği 40 metre olup genel bakısı güney-batıdır. Fidanlığın yıllık ortalama sıcaklık değeri $19,2^{\circ} \mathrm{C}$ ' dir. Fidanlığın genel alanı 162 dekardır. Fidan yetiştirme alanı 131 dekar, ekim alanı 47 dekar, tüplü ve kaplı fidan üretim alanı 34 dekar, saksılı fidan üretim alanı 14,1 dekar, yere repikajı fidan üretim alanı 25 dekar, fidan satış alanı 0,8 dekardir.

Toprak türü Batı Akdeniz Ormancılık Araştırma Enstitüsü Müdürlüğü'nün 07.03.2018 tarihli tahlil sonuçlarına göre balçık sınıfındadır. Parsellerin tamamının Ph oranı 8.24 ila 8.33 arasında değişmekte olup, orta alkali sınıfındadır. Genel olarak çok yüksek kireç içermektedir. Az seviyede organik madde bulunmaktadır. Tuzluluk oranı olarak az tuzlu sınıfındadır. Total olarak azot tüm parsellerde az miktardır. Sodyum ve fosfor yeterli seviyedir. Potasyum olarak düşük sevidedir. Kalsiyum olarak yüksek miktarda kalsiyum içermektedir.

\section{Materyal}

Çalışmada, Antalya Orman Fidanlığında yetiştirilen ve yöreden fenotipik (boy, çap, habitus) olarak örneklenen tohum ağaçlarından elde edilen Dallı servi (Tohum Toplama Sahası- TTS-2772) ve çalışmada Piramit servi olarak adlandırılan Ehrami servi (TTS-2807) orijinli ve 1+0 yaşı çıplak köklü fidanlarından 2019 yılı sonbaharında her taksondan 150'şer adet olmak üzere rastgele örneklenen 300 fidan örneklenmiştir (Şekil 1). 

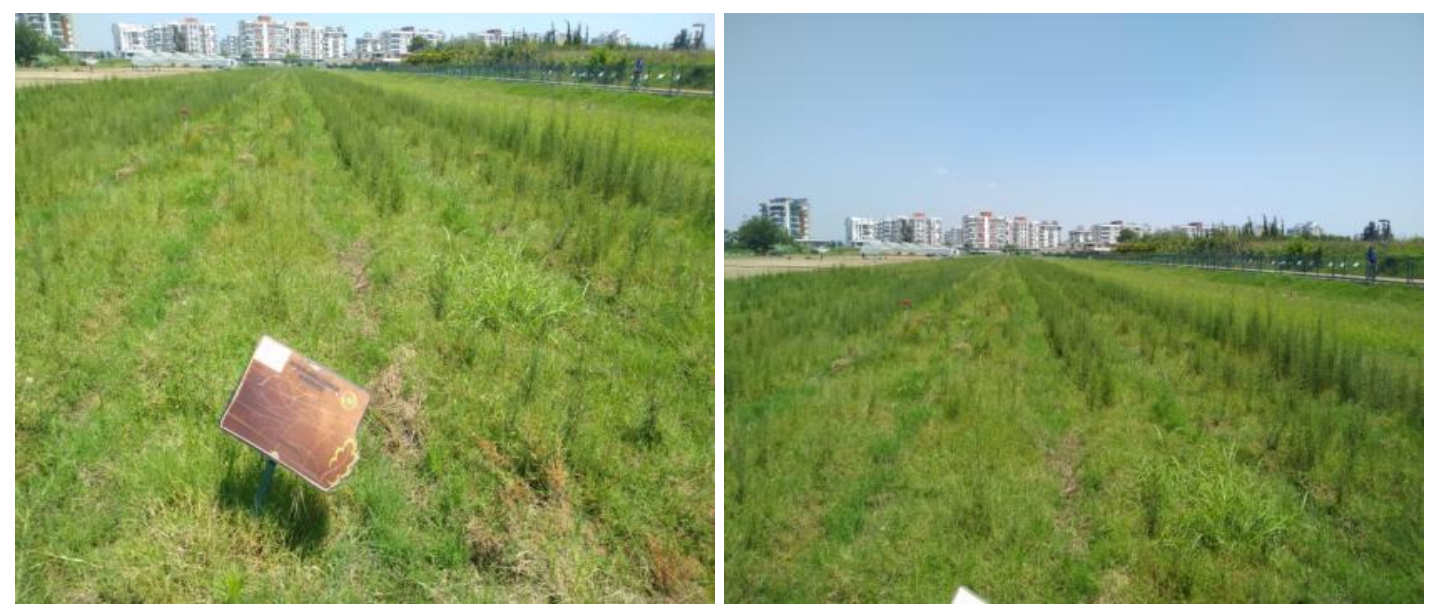

Şekil 1. Çalışmada kullanılan dallı servi ve piramit servi fidanları

\section{Yöntem}

Çalışmada, fidan kalitesinde ve ağaçlandırmanın başarısında önemli rol oynayan morfolojik özelliklerden fidan boyu (FB) ve kök boğazı çapı (KBÇ) kullanıımıştır.

Elde edilen veriler SPSS paket programında değerlendirilerek temel istatistiksel değerler belirlenmiştir. Kalite sınıflarının çalışmaya konu fidanlara uygunluğu yani başarı durumu diskriminant analizi ile denetlenmiştir. Bun- larla birlikte fidan boyu ve kök boğazı çapı arasındaki fenotipik ilişkiler yani Pearson korelasyon katsayıları tahmin edilmiş; fidan boyu ve kök boğazı çapı bakımından taksonlar basit varyans analizi (ANOVA) ile karşılaştırılmıştır.

Yapılan ölçümlere göre fidanlar; boy, kök boğazı çapı ile boy ve kök boğazı çapı bakımından Türk Standartları Enstitüsü'nün kalite sınıflarına (TS/2265) (Tablo 1) (Anonim, 1988) tabi tutulmuştur.

Tablo 1. TSE'ye göre türün fidan boyu ve kök boğazı çapı için $1+0$ yaşı fidan kalite sınıfları

\begin{tabular}{cccc}
\hline Kalite sınıfı & $\begin{array}{c}\text { Fidan boyu } \\
\text { (FB }, \mathbf{c m})\end{array}$ & $\begin{array}{c}\text { Kök boğazı çapı } \\
\text { (KBÇ, } \mathbf{m m})\end{array}$ & FB+KBÇ \\
I. sınıf & $18 \leq$ & $2 \leq$ & $18 \leq \mathrm{FB}+2 \leq \mathrm{KBCC}$ \\
II. sınıf & $18>\mathrm{FB} \geq 15$ & $2 \leq$ & $18>\mathrm{FB} \geq 15+2 \leq \mathrm{KBC}$ \\
Elverişsiz & $15>$ & $2>$ & $15>\mathrm{FB}+2>\mathrm{KBÇ}$ \\
\hline
\end{tabular}

Literatürsel bilgilerde fidan kalite sınıflarının fidanlık bazında yapılması gerektiği düşüncesinden hareketle, boy ve kök boğazı çapına ait aritmetik ortalama $(\bar{x})$ ve standart sapma (S) değerleri yardımıyla $(\bar{x} \pm S)$ taksonlara göre yeni kalite sınıfları oluşturulmuş (Tablo 2) (Bilir, 1997) ve bu kalite sınıfları diskriminant (ayırma) analizi ile denetlenmiştir. 
Tablo 2. Yeni sınıflandırmaya göre taksonlar için fidan kalite sınıfları

\begin{tabular}{|c|c|c|c|}
\hline Kalite sınıfı & $\begin{array}{c}\text { Fidan boyu } \\
(\mathrm{FB}, \mathrm{cm})\end{array}$ & $\begin{array}{c}\text { Kök boğazı çapı } \\
\text { (KBÇ, mm) }\end{array}$ & $\mathrm{FB}+\mathrm{KBC}$ \\
\hline \multicolumn{4}{|c|}{ Dallı Servi } \\
\hline $\begin{array}{l}\text { I. sinif } \\
\text { II. sinıf } \\
\text { Elverissiz }\end{array}$ & $\begin{array}{c}86 \leq \\
86>F B \geq 80 \\
80>\end{array}$ & 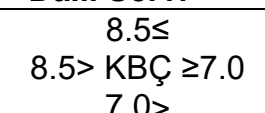 & $\begin{aligned} 86 & \leq \mathrm{FB}+8.5 \leq \mathrm{KBÇ} \\
86>\mathrm{FB} & \geq 80+8.5>\mathrm{KBÇ} \geq 7.0 \\
80 & >\mathrm{FB}+70>\mathrm{KBC}\end{aligned}$ \\
\hline \multicolumn{4}{|c|}{ Piramit Servi } \\
\hline $\begin{array}{l}\text { I. sınıf } \\
\text { Il. sınıf } \\
\text { Elverissiz }\end{array}$ & $\begin{array}{c}80 \leq \\
80>F B \geq 75 \\
75>\end{array}$ & $\begin{array}{l}9.0 \leq \\
9.0>\mathrm{KBÇ} \geq 7.0 \\
7.0>\end{array}$ & $\begin{array}{c}80 \leq \mathrm{FB}+9.0 \leq \mathrm{KBÇ} \\
80>\mathrm{FB} \geq 75+9.0>\mathrm{KBÇ} \geq 7.0 \\
75>\mathrm{FB}+7.0>\mathrm{KBC}\end{array}$ \\
\hline \multicolumn{4}{|c|}{ Akdeniz Servisi (Dallı ve Piramit) } \\
\hline $\begin{array}{l}\text { I. sınıf } \\
\text { Il. sınıf } \\
\text { Elverişsiz }\end{array}$ & $\begin{array}{c}85 \leq \\
85>F B \geq 78 \\
78>\end{array}$ & $\begin{array}{c}9.0 \leq \\
9.0>\mathrm{KBÇ} \geq 7.5 \\
7.5>\end{array}$ & $\begin{aligned} 85 \leq \mathrm{FB}+9.0 \leq \mathrm{KBÇ} \\
85>\mathrm{FB} \geq 78+9.0>\mathrm{KBÇ} \geq 7.5 \\
78>\mathrm{FB}+7.5>\mathrm{KBÇ}\end{aligned}$ \\
\hline
\end{tabular}

\section{BULGULAR VE TARTIŞMA}

\section{Morfolojik Özellikler}

Fidan boyu ve kök boğazı çapı bakımından gerek takson içi ve gerekse taksonlar arası geniş farklılıklar bulunmakla birlikte, ortalama fidan boyu ve kök boğazı çapı değerleri sırasıyla Dallı servide $84 \mathrm{~cm}$ ve $8,7 \mathrm{~mm}$; Piramit servide $78,9 \mathrm{~cm}$ ve $8,2 \mathrm{~mm}$; her iki taksonun oluşturduğu Akdeniz servisinde ise $81,4 \mathrm{~cm}$ ve $8,4 \mathrm{~mm}$ bulunmuştur (Tablo 3).

Tablo 3. Taksonlara göre fidan boyu ve kök boğazı çapı değerleri

\begin{tabular}{ccccccc}
\hline & \multicolumn{2}{c}{ Dallı Servi } & \multicolumn{2}{c}{ Piramit Servi } & \multicolumn{2}{c}{ Akdeniz Servisi } \\
& FB & KBÇ & FB & KBÇ & FB & KBÇ \\
\hline Ortalama & 84.0 & 8.66 & 78.9 & 8.20 & 81.4 & 8.43 \\
Minimum & 67.5 & 5.10 & 62.50 & 5.33 & 62.50 & 5.10 \\
Maksimum & 98.25 & 12.70 & 94.18 & 11.50 & 98.25 & 12.70 \\
St. sapma & 5.83 & 1.47 & 7.17 & 1.46 & 6.99 & 1.48 \\
\hline
\end{tabular}

Türün 17 populasyonunda gerçekleştirilen çalışmada da fidan boyu ve kök boğazı çapı bakımından populasyonlar arası ve populasyon içinde aileler arasında önemli düzeyde genetik farklılıklar belirtilmiştir (Sabuncu, 2004).

Sabuncu (2004), Akdeniz servisinin Finlandiya tipi tepsi tüplerde yetiştirilen 17 popülasyona ait fidanlarında birinci büyüme mevsimi sonunda gerçekleştirilen ölçümler ışığında ortalama fidan boyunun popülasyonlarda 22,8 cm (Marmaris)-32,6 cm (Bozyazı) arasında kök boğazı çapının ise 3,4 mm (Yunanistan)- 4,6 mm (Bozyazı) arasında değiştiğini belirlemiştir. Sabuncu (2004) tarafından elde edilen bu değerler tarafımızca elde edilen değerlere (Tablo 1) göre oldukça düşük olup, fidan morfolojisine tohum kaynağından yetiştirme ortamı ve fidanlık tekniği gibi birçok genetik ve çevresel faktörlerin etkili olduğu bilinmektedir.

Çalışmada elde edilen ortalama değerler (Tablo 1) yörenin doğal orman ağacı türlerinden olan Toros Sediri (Cedrus libani A. Rich) ve Kızılçam'ın (Pinus brutia Ten.) performansından oldukça yüksektir. Toros sediri'nin 1+0 yaşlı tüplü ve çıplak köklü fidanları üzerinde gerçekleştirilen çalışmada fidan boyu ve kök boğazı çapı sırasıyla, tüplü fidanlarda $13,1 \mathrm{~cm}$ ve 3,02 mm; çıplak köklü fidanlarda ise $6,2 \mathrm{~cm}$ ve $2.07 \mathrm{~mm}$ bulunmuştur (Çetinkaya ve Bilir, 2014). Yörenin bir başka türü olan ve Türkiye'de en geniş doğal yayılışa sahip Kızılçam'ın Antalya Orman Fidanlığında yetiştirilen fidanları üzerinde gerçekleştirilen çalışmada, türün $1+0$ yaşlı çıplak köklü ve $1+1$ yaşlı tüplü fidanlarında ortalama fidan boyu sırasıyla $8,2 \mathrm{~cm}$ ve $16,5 \mathrm{~cm}$, kök boğazı çapı ise $3,97 \mathrm{~mm}$ ve $5,84 \mathrm{~mm}$ bulunmuştur (Bilir, 2019). Kızılçam'ın Osmaniye Orman Fidanlığında üretilen, 1+0 yaşlı çıplak köklü ve tüplü fidanlarında ise ortalama fidan boyu ve kök boğazı çapını sırasıyla $18,4 \mathrm{~cm}$ ve $4.86 \mathrm{~mm}$ belirlemişlerdir (Yılmazer ve Bilir, 2016). Dursunbey Orman Fidanlığı koşullarında yetiştirilen tohum meşceresi ve tohum Bahçesi orijinli $1+0$ yaşlı çıplak köklü ve tüplü Kızılçam fidanlarında ortalama fidan boyunu $12,5 \mathrm{~cm}$, kök boğazı çapını ise 2,74 mm bulunmuştur (Dilaver ve ark., 2015). Bu sonuçlar çaIışmaya konu Servi taksonlarının yüksek büyüme performansı ile ağaçlandırma uygulamalarındaki kullanım potansiyelini de açıkca göstermektedir. Örneğin, Özel ve ark. (2018), Kızılçam'ın 1+0 yaşlı çıplak köklü, 1+1yaşlı 
tüplü ve 1+0 yaşlı enso tipli fidanlarında gerçekleştirmiş olduğu çalışmada fidan boyunu $(5,7 \mathrm{~cm})$ ve kök boğazı çapını $(1,5 \mathrm{~mm})$ en düşük enso tipli fidanlarda belirlerken; uyguladıkları varyans analizi sonucunda morfolojik özellikler bakımından fidan tipleri arasında anlamlı farkIılıklar belirlemişlerdir.
Tablo 1'den de görüldüğü üzere fidan boyu ve kök boğazı çapı bakımından Dallı servi, Piramit serviye göre daha yüksek performans göstermiştir. Her iki taksonda da boy bakımından en düşük birey ile en yüksek birey arasında yaklaşık \%50'lik fark söz konusu olup bu fark kök boğazı çapı için \%100'ün üzerindedir (Şekil 2).

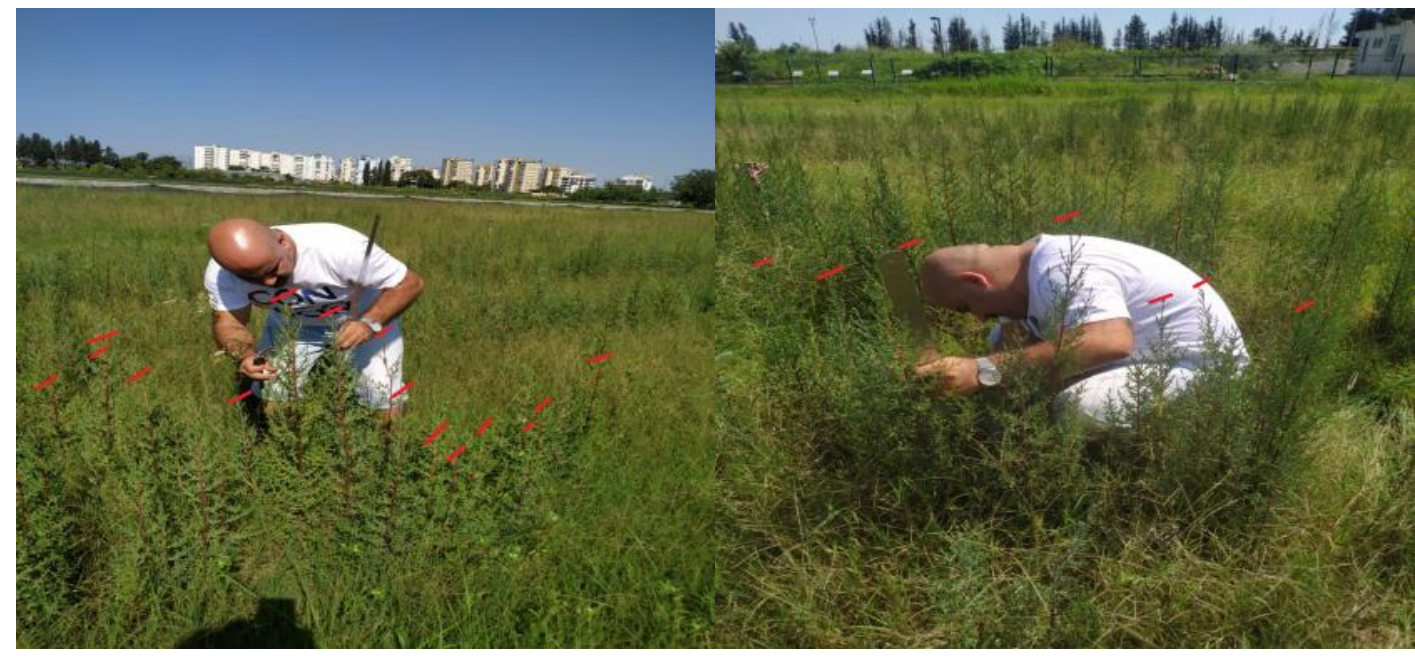

Şekil 2. Taksonlarda boy farklılıkları

Uygulanan varyans analizi sonucunda fidan boyu ve kök boğazı çapı bakımından taksonlar arası anlamlı $(p \leq 0.05)$ fark ortaya çıkmıştır.

Gerek fidan boyu ve kök boğazına ilişkin standart sapma değerleri (Tablo 1) ve gerekse varyans analizi sonuçları her iki taksonda da fidan boyunun kök boğazı çağına göre daha yüksek varyasyona sahip olduğunu göstermektedir. Sabuncu (2004) tarafından Akdeniz servisinin 17 popülasyonuna ait fidanlar üzerinde gerçekleştirilen çalışmada da popülasyonların fidan boyu bakımından 10 homojen grup kök boğazı çapı bakımından ise 7 homojen grup oluşturduğu belirlenmiş ve fidan boyu bakımından populasyon içi genetik çeşitliliğin yüksekliğinin, kalıtsallık derecesinin büyüklüğü ile de desteklendiği ifade edilmiştir. Bu sonuçlar türde seleksiyon çalışmalarında fidan boyunu kök boğazı çapına oranla daha ön plana çıkarmaktadır.

\section{Morfolojik Özellikler Arasındaki İlişkiler}

Uygulanan korelasyon analizi sonucunda Dallı servi ve Piramit servi ile bu taksonların türü olan Akdeniz servisinde; fidan boyu ile kök boğazı arasındaki istatistiksel bakımdan anlamlı $(p \leq 0.05)$ pozitif ilişkiler $(r=0.299$, $r=0.255$ ve $r=0.308$ ) belirlenmiştir.

Çalışmamızda ortaya çıkan bu pozitif ilişkiler değiş̧ik iğne yapraklı orman ağacı türlerinde de belirlenmiştir. Örneğin, 1+0 yaşlı tüplü ve çıplak köklü Toros sediri fidanları üzerinde gerçekleştirilen çalışmada fidan boyu ve kök boğazı çapı arasında (Çetinkaya ve Bilir, 2014); Osmaniye Orman Fidanlığında yetiştirilen $1+0$ yaşlı çıplak köklü ve 1+1 yaşlı tüplü Kızılçam fidanlarında fidan boyu ve kök boğazı çapı arasında (Yılmazer ve Bilir, 2016); Antalya Orman Fidanlığında yetiştirilen $1+0$ yaşlı çıplak köklü ve 1+1 yaşlı tüplü Kızılçam fidanlarında fidan boyu ve kök boğazı çapı arasında (Bilir, 2019); Dursunbey Orman Fidanlığı koşullarında yetiştirilen tohum meşceresi ve tohum bahçesi orijinli $1+0$ yaşlı çıplak köklü ve tüplü Kızılçam fidanlarında fidan boyu ve kök boğazı çapı arasında (Dilaver ve ark., 2015); Kızılçam'ın değişik fidan tiplerine ait fidanlarında fidan boyu ve kök boğazı çapı arasında (Özel ve ark., 2018); Karaçam'ın değişik yaş ve tipteki fidanlarında fidan boyu ve kök boğazı çapı arasında (Tebeş ve ark., 2015) anlamlı $(p \leq 0.05)$ pozitif ilişkiler belirlenmiştir. Gerek çalışmamızda ve gerekse önceki çalışmalarda ortaya çıkan bu anlamlı ilişkiler ileriki çalışmalarda sadece bir özelliğin kullanılabileceğini de göstermektedir.

\section{Fidan Kalitesi ve Denetlenmesi}

\section{Dallı servide fidan kalitesi ve denetlenmesi}

Yapılan değerlendirmeler ışığında, Dallı servi fidanlarının tamamının Türk Standartları Enstitüsü'nün kalite Sınıflarına (Anonim, 1988; Tablo 1) göre kaliteli fidan sınıfında yer almakta olup bu nedenle TSE kalite sınıflarının başarı durumu ayırma analizi ile denetlenememiştir. Bu taksona ait fidanların, çalışma kapsamında oluşturulan 
yeni kalite sınıflarına (Tablo 2) dağılımı Tablo 4'te verilmiştir. Tablo 4'ten de görüldüğü üzere fidanların gerek takson ve gerekse tür bazında oluşturulan yeni kalite sınıflarına (Tablo 2) dağılımı irdelendiğinde en yüksek dikime elverişsiz fidanların boy ve çapın birlikte değerlen- dirildiği kalite sınıflarında (\%36 ve \%26,7) olduğu anlaşılmaktadır. Bununla birlikte fidan kalitesi bakımından fidanların kök boğazı çapı bakımından fidan boyuna oranla daha iyi bir gelişim performansı yaptığı görülmektedir (Tablo 4).

Tablo 4. Dallı servide fidanların kalite sınıflarına dağılımı (\%)

\begin{tabular}{ccccccc}
\hline $\begin{array}{c}\text { Kalite } \\
\text { SInıfı }\end{array}$ & FB & Dallı Servi & \multicolumn{4}{c}{ Akdeniz Servisi (Dallı ve Piramit) } \\
\hline I. Sınıf & 37.3 & 54.7 & FB+KBÇ & FB & KBÇ & FB+KBÇ \\
II. sınıf & 37.3 & 30.7 & 36.7 & 44.0 & 43.3 & 27.3 \\
Elverişsiz & 25.3 & 14.7 & 36.0 & 40.0 & 42.0 & 46.0 \\
\hline
\end{tabular}

Oluşturulan bu yeni kalite sınıflarının, çalışmaya konu taksona uygunluğunu denetlemek amacıyla uygulanan ayırma analizi sonucunda yeni oluşturulan kalite sınıflarının, \%82- \%98 arasında değişen oranlarda başarılı olduğu görülmektedir (Tablo 5). Başarı oranlarında fidan boyu ve kök boğazı çapı kombinasyonunun diğer kriterlere oranla başarı durumunun daha düşük olduğu söylenebilir (Tablo 5).

Tablo 5. Dallı servide yeni kalite sınıflarının ayırma analizi ile denetlenmesi

\begin{tabular}{|c|c|c|c|c|}
\hline \multicolumn{5}{|c|}{ Dallı Servi kalite sınıfı } \\
\hline \multirow[t]{2}{*}{ Gerçek gruplar } & \multicolumn{4}{|c|}{ Belirlenen gruplar (adet, \%) } \\
\hline & 1 & 2 & 3 & Toplam \\
\hline $\begin{array}{c}\text { FB için (\%94.7) } \\
1 \\
2 \\
3 \\
\end{array}$ & $\begin{array}{c}51-91.1 \\
0 \\
0\end{array}$ & $\begin{array}{c}5-8.9 \\
56-100 \\
3-7.9\end{array}$ & $\begin{array}{c}0 \\
0 \\
35-92.1\end{array}$ & $\begin{array}{l}56 \\
56 \\
38\end{array}$ \\
\hline $\begin{array}{c}\text { KBÇ için (\%93.3) } \\
1 \\
2 \\
3 \\
\end{array}$ & $\begin{array}{c}76-92.7 \\
0 \\
0\end{array}$ & $\begin{array}{c}6-7.3 \\
46-100.0 \\
4-18.2\end{array}$ & $\begin{array}{c}0 \\
0 \\
18-81.8\end{array}$ & $\begin{array}{l}82 \\
46 \\
22\end{array}$ \\
\hline $\begin{array}{c}\mathrm{FB}+\mathrm{KBÇ} \text { için (\%82) } \\
1 \\
2 \\
3 \\
\end{array}$ & $\begin{array}{c}37-90.2 \\
4-7.3 \\
0 \\
\end{array}$ & $\begin{array}{c}4-9.8 \\
44-80.0 \\
12-22.2 \\
\end{array}$ & $\begin{array}{c}0 \\
7-12.7 \\
42-77.8 \\
\end{array}$ & $\begin{array}{l}41 \\
55 \\
54\end{array}$ \\
\hline \multicolumn{5}{|c|}{ Akdeniz Servisi (Dallı ve Piramit) kalite sınıfı } \\
\hline $\begin{array}{c}\text { FB için (\%94.0) } \\
1 \\
2 \\
3 \\
\end{array}$ & $\begin{array}{c}59-89.4 \\
0 \\
0 \\
\end{array}$ & $\begin{array}{c}7-10.6 \\
60-100 \\
2-8.3\end{array}$ & $\begin{array}{c}0 \\
0 \\
22-91.7\end{array}$ & $\begin{array}{l}66 \\
60 \\
24\end{array}$ \\
\hline $\begin{array}{c}\text { KBÇ için (\%98.0) } \\
1 \\
2 \\
3 \\
\end{array}$ & $\begin{array}{c}64-98.5 \\
0 \\
0\end{array}$ & $\begin{array}{c}1-1.5 \\
63-100 \\
2-9.1\end{array}$ & $\begin{array}{c}0 \\
0 \\
20-90.9\end{array}$ & $\begin{array}{l}65 \\
63 \\
22\end{array}$ \\
\hline $\begin{array}{c}\mathrm{FB}+\mathrm{KBÇ} \text { için } \\
(\% 84.0) \\
1 \\
2 \\
3\end{array}$ & $\begin{array}{c}37-90.2 \\
3-4.3 \\
0\end{array}$ & $\begin{array}{c}4-9.8 \\
59-85.5 \\
10-25.0\end{array}$ & $\begin{array}{c}0 \\
7-10.2 \\
30-75.0\end{array}$ & $\begin{array}{l}41 \\
69 \\
10\end{array}$ \\
\hline
\end{tabular}




\section{Piramit servide fidan kalitesi ve denetlenmesi}

Elde edilen sonuçlar ışığında Piramit servi fidanlarının tamamının Türk Standartları Enstitüsü'nün kalite sınıflarına (Tablo 1) (Anonim, 1988) göre kaliteli fidan sınıfında yer aldığı anlaşılmış olup bu nedenle TSE kalite sınıflarının başarı durumu ayırma analizi ile denetlenememiş- tir. Bu taksona ait fidanların çalışma kapsamında oluşturulan, yeni kalite sınıflarına (Tablo 2) dağılımına göre fidanların gerek takson ve gerekse tür bazında, dikime elverişsiz fidanların fidan boyu ve kök boğazı çapının birlikte değerlendirildiği kalite sınıflarında (\%42,7 ve $\% 52,7$ ) yer aldığı görülmektedir (Tablo 6).

Tablo 6. Piramit servide fidanların kalite sınıflarına dağılımı (\%)

\begin{tabular}{ccccccc}
\hline Kalite & \multicolumn{3}{c}{ Piramit Servi } & \multicolumn{3}{c}{ Akdeniz Servisi (Dallı ve Piramit) } \\
sınıfı & FB & KBÇ & FB+KBÇ & FB & KBÇ & FB+KBÇ \\
\hline I. Sınıf & 48.0 & 28.7 & 14.7 & 22.0 & 28.7 & 10.0 \\
II. Sınıf & 22.0 & 46.7 & 42.7 & 35.3 & 44.0 & 37.3 \\
Elverişsiz & 30.0 & 24.7 & 42.7 & 42.7 & 27.3 & 52.7 \\
\hline
\end{tabular}

Dallı servi fidanlarının aksine Piramit servi fidanlarında, fidan kalitesi bakımından fidanların boy bakımından çapa oranla daha iyi bir gelişim performansı yaptığı görülmektedir (Tablo 6).
Uygulanan ayırma analizi sonucunda yeni oluşturulan kalite sınıflarının, \%80,0-96,7 arasında değişen oranlarda başarılı olduğu görülmektedir (Tablo 7). Başarı oranlarında fidan boyu ve kök boğazı çapı kombinasyonunun diğer kriterlere oranla başarı durumunun daha düşük olduğu söylenebilir (Tablo 7).

Tablo 7. Piramit servide yeni kalite sınıflarının ayırma analizi ile denetlenmesi

\begin{tabular}{|c|c|c|c|c|}
\hline \multicolumn{5}{|c|}{ Piramit Servi kalite sınıfı } \\
\hline \multirow[t]{2}{*}{ Gerçek gruplar } & \multicolumn{4}{|c|}{ Belirlenen gruplar (adet, \%) } \\
\hline & 1 & 2 & 3 & Toplam \\
\hline $\begin{array}{c}\text { FB için (\%94.7) } \\
1 \\
2 \\
3 \\
\end{array}$ & $\begin{array}{c}72-100.01 \\
2-6.1 \\
0 \\
\end{array}$ & $\begin{array}{c}0 \\
30-90.9 \\
5-11.1\end{array}$ & $\begin{array}{c}0 \\
1-3.0 \\
40-88.9 \\
\end{array}$ & $\begin{array}{l}72 \\
33 \\
45\end{array}$ \\
\hline $\begin{array}{c}\text { KBÇ için (\%96.7) } \\
1 \\
2 \\
3 \\
\end{array}$ & $\begin{array}{c}40-93.0 \\
1-1.4 \\
0 \\
\end{array}$ & $\begin{array}{c}3-7.0 \\
68-97.1 \\
0 \\
\end{array}$ & $\begin{array}{c}0 \\
1-1.4 \\
37-100.0 \\
\end{array}$ & $\begin{array}{l}43 \\
70 \\
37\end{array}$ \\
\hline $\begin{array}{c}\mathrm{FB}+\mathrm{KBÇ} \text { için } \\
(\% 80.0) \\
1 \\
2 \\
3 \\
\end{array}$ & $\begin{array}{c}15-68.2 \\
4-6.3 \\
0\end{array}$ & $\begin{array}{c}7-31.8 \\
51-79.7 \\
10-15.6\end{array}$ & $\begin{array}{c}0 \\
9-14.1 \\
54-84.4\end{array}$ & $\begin{array}{l}22 \\
64 \\
64\end{array}$ \\
\hline \multicolumn{5}{|c|}{ Akdeniz Servisi (Dallı ve Piramit) kalite sınıfı } \\
\hline $\begin{array}{c}\text { FB için (\%86.7) } \\
1 \\
2 \\
3 \\
\end{array}$ & $\begin{array}{c}24-72.7 \\
0 \\
0 \\
\end{array}$ & $\begin{array}{c}9-27.3 \\
51-96.2 \\
9-14.1 \\
\end{array}$ & $\begin{array}{c}0 \\
2-3.8 \\
55-85.9 \\
\end{array}$ & $\begin{array}{l}33 \\
53 \\
64 \\
\end{array}$ \\
\hline $\begin{array}{c}\text { KBÇ için (\%92.0) } \\
1 \\
2 \\
3 \\
\end{array}$ & $\begin{array}{c}38-88.4 \\
2-3.0 \\
0\end{array}$ & $\begin{array}{c}5-11.6 \\
62-94.0 \\
3-7.3 \\
\end{array}$ & $\begin{array}{c}0 \\
2-3.0 \\
38-92.7\end{array}$ & $\begin{array}{l}43 \\
66 \\
41\end{array}$ \\
\hline $\begin{array}{c}\mathrm{FB}+\mathrm{KBÇ} \text { için } \\
(\% 82.7) \\
1 \\
2 \\
3 \\
\end{array}$ & $\begin{array}{c}5-33.3 \\
1-1.8 \\
0\end{array}$ & $\begin{array}{l}10-66.7 \\
50-89.3 \\
10-12.7\end{array}$ & $\begin{array}{c}0 \\
5-8.9 \\
69-87.3\end{array}$ & $\begin{array}{l}15 \\
56 \\
79\end{array}$ \\
\hline
\end{tabular}




\section{Akdeniz servisinde fidan kalitesi ve denetlenmesi}

Çalışmaya konu taksonlardan Dallı servi ve Piramit servinin birlikte yani Akdeniz servisi olarak değerlendirilmesi sonucunda fidanların tamamı Türk Standartları Enstitüsü'nün kalite sınıflarına (Tablo 1) (Anonim, 1988) göre kaliteli fidan sınıfında yer aldığından TSE kalite sı- nıflarının başarı durumu ayırma analizi ile denetlenememiştir. Bu taksonlara ait fidanların birlikte değerlendirilmesi sonucu, oluşturulan yeni kalite sınıflarına (Tablo 2) göre fidanların boy için \%29'unun, çap için \%21'inin, fidan boyu ve kök boğazı çapı birlikteliği içinse \%39,7'sinin dikime elverişsiz fidan sınıfında yer aldığı belirlenmiştir (Tablo 8).

Tablo 8. Akdeniz servisinde fidanların kalite sınıflarına dağılımı (\%)

\begin{tabular}{cccc}
\hline Kalite sınıfı & FB & $\begin{array}{c}\text { Akdeniz Servisi (Dallı ve Piramit) } \\
\text { KBÇ }\end{array}$ & FB+KBÇ \\
\hline I. sınıf & 33.0 & 36.0 & 18.7 \\
II. sınıf & 37.7 & 43.0 & 41.7 \\
Elverişsiz & 29.3 & 21.0 & 39.7 \\
\hline
\end{tabular}

Oluşturulan bu yeni kalite sınıflarının, çalışmaya konu türe uygunluğunu denetlemek amacıyla uygulanan ayırma analizi sonucunda ise kalite sınıfının fidan boyu için \%89,3, kök boğazı çapı için \%94,7, fidan boyu ve kök boğazı çapı birlikteliği içinse $\% 82$ oranında başarıı olduğu ortaya çıkmıştır (Tablo 9).

Tablo 9. Akdeniz servisinde yeni kalite sınıflarının denetlenmesi

\begin{tabular}{|c|c|c|c|c|}
\hline \multicolumn{5}{|c|}{ Akdeniz Servisi (Dallı ve Piramit) kalite sınıfı } \\
\hline FB için (\%89.3) & & & & \\
1 & $87-87.9$ & $12-12.1$ & 0 & 99 \\
2 & 0 & $111-98.2$ & $2-1.8$ & 113 \\
3 & 0 & $18-20.5$ & $70-79.5$ & 98 \\
\hline KBÇ için (\%94.7) & & & & \\
1 & $102-94.4$ & $6-5.6$ & 0 & 108 \\
2 & $2-1.6$ & $124-96.1$ & $3-2.3$ & 129 \\
3 & 0 & $5-7.9$ & $58-92.1$ & 63 \\
\hline FB+KBÇ için & $41-73.2$ & $15-26.8$ & 0 & 56 \\
$(\% 82.0)$ & $7-5.6$ & $106-84.8$ & $12-9.6$ & 125 \\
1 & 0 & $20-16.8$ & $99-83.2$ & 119 \\
2 & & & & \\
3 & & & &
\end{tabular}

Uygulanan ayırma analizi sonucunda yeni oluşturulan kalite sınıflarının, \%82-94,7 arasında değişen oranlarda başarılı olduğu görülmektedir. Başarı oranlarına fidan boyu ve kök boğazı çapı kombinasyonunun diğer kriterlere oranla başarı durumunun daha düşük olduğu söylenebilir (Tablo 9).

Oluşturulan kalite sınıfları sonucunda Dallı servi fidanlarının bu boya özgü kalite sınıfında $\% 37,3$ 'ünün 1 . sınıfta ve \%25,3'ünün dikime elverişsiz fidan sınıfında; tür bazında oluşturulan kalite sınıfında ise \%44'ünün 1 . sınıfta ve \%16'sının dikime elverişsiz fidan olduğu (Tablo 4); Piramit servide ise taksona özgü oluşturulan kalite sınıfında \%48'inin 1. sınıfta ve \%30'unun dikime elverişsiz fidan sınıfında tür bazında oluşturulan kalite sınıfında ise $\% 22$ 'sinin 1. sınıfta ve \%42,7'sinin dikime elverişsiz fidan olduğu (Tablo 6 ) belirlenirken TSE kalite sınıflarına göre boy bakımından her iki taksona ait fidanların tamamının kaliteli yani dikime elverişli olduğu ortaya çıkmış- tır. Bu sonuç fidan kalite sınıfının takson bazında oluşturulmasının önemini bir kez daha vurgulamaktadır. Buna karşın Servi taksonlarına ilişkin uygulamda mevcut olan Türk Standartları Enstitüsü'nün kalite sınıfları (TS/2265); Dallı servi, Piramit servi, Arizona servisi, Kokulu servi, Yalancı servi, Avrupa melezi, Japon mazısı ve Kriptomerya için ortak değerlere sahiptir ve kök boğazı çapı, tür, fidan tipi ve yaşı ayırt edilmeksizin minimum $2 \mathrm{~mm}$ olarak kabul edilmektedir (Anonim, 1988). Oysa, bilindiği üzere fidan morfolojisi ve kalitesi üzerine fidanlığın konumu ve fidanlık tekniği gibi bir çok çevresel (Atasoy, 1986; Dewald ve Feret, 1987) ve tür, alt tür, seleksiyon gibi birçok genetiksel (Parker ve Niejenhuis, 1994; Gülcü ve ark., 2000, vb.) faktörler etkili olabilmektedir. Örneğin; Üçler ve ark. (2000) doğal Anadolu Karaçamı ve Kızılçam meşçerelerinden fenotipik olarak örneklemiş oldukları ailelere ilişkin fidanlarda seleksiyonun önemini vurgulamışlardır. Aynı çalışmada, TSE kalite sınıflarının Anadolu Karaçamı'nda \%87,8, Kızılçamda ise \%82,7 oranında başarılı olduğunu belirlemişlerdir; fıstıkçamı 
(Pinus pinea L.) fidanlarında ise bu oran \%90'ın üzerinde çıkmıştır (Bilir ve ark., 2010). 1+0 ve 1+1 yaşı Kızılçam fidanları üzerinde gerçekleştirilen çalışmada ise, fidan boyu ve kök boğazı çapı bakımından TSE kalite sınıflarının her iki fidan yaş grubu için başarılı olduğu belirlenmiştir (Bilir, 2019). Dilaver ark. (2015) tarafından Kızılçam fidanları için fidan boyu ve kök boğazı çapına göre oluşturulan kalite sınıflarının ayırma analizi ile denetlenmesi sonucu sınıflandırmanın \%90'ın üzerinde başarılı olduğu ortaya çıkmıştır.

Tebeş ve ark. (2015) Karaçam'ın (Pinus nigra Arnold. subsp. pallasiana) Çankırı ve Çerkeş Orman Fidanlıklarında yetiştirilen 2-0 ve 3-0 yaşıı tüplü ve çıplak köklü fidanlarda gerçekleştirdiği çalışmada, kök boğazı çapı bakımından fidanların tamamının, TSE kalite sınıflarına göre kaliteli fidan sınıfında yer aldığını, boy bakımından ise fidanların \% 7,2'sinin dikime elverişsiz olduğunu belirlemişler; tüplü fidanların, çıplak köklü fidanlara oranla daha yüksek oranda kaliteli fidana sahip olduğunu ortaya çıkarmışlardır. TSE kalite sınıflarının diskriminant analizi ile denetlenmesi sonucunda, kalite sınıfının başarı durumunun çıplak köklü fidanlarda \%30-\%46 arasında değiştiği, 2-0 yaşlı tüplü fidanlarda ise $\% 90$ oranında başarılı olduğu belirlemişlerdir. Çalışma kapsamında oluşturulan yeni kalite sınıflarının başarı durumu ise uygulanan ayırma analizi sonucunda başarı durumunun fidan tip ve yaşı ile kalite kriterine göre değişim gösterdiği belirlenmiştir (Tebeş ve ark., 2015).

Fidan kalite sınıflarının oluşturulmasında, kalite sınıflarının fidanlık aşaması ile arazi aşamasının birlikte değerlendirilmesi gerekmektedir (Eyüboğlu ve Karadeniz, 1987; Kızmaz, 1993). Bu hususa ilişkin olarak Toros sediri üzerinde gerçekleştirilen çalışmada, fidanlıkta yüksek gelişme performansa sahip bireylerin arazide de bu performansını devam ettirdiğini ortaya çıkarmıştır (Eler ve ark., 1993).

Bu sonuçlar fidan morfolojisi ve kalitesi üzerine etkili olan çevresel ve genetiksel faktörlerin önemini bir kez daha vurguladığı gibi, TSE fidan kalite sınıfında esas alınan minimum 2 mm kök boğazı çapı kriterinin tür, yaş, fidan tipine göre değiştirilmesi gerektiğinin aciliyetini de vurgulamaktadır.

\section{SONUÇLAR}

Çalışmaya konu fidan boyu ve kök boğazı çapı bakımından takson içi ve taksonlar arası geniş farklılıklar bulunmakla birlikte, ortalama fidan boyu ve kök boğazı çapı değerleri sırasıyla Dallı servide $84 \mathrm{~cm}$ ve $8,7 \mathrm{~mm}$; Piramit servide $78,9 \mathrm{~cm}$ ve $8,2 \mathrm{~mm}$; her iki taksonun oluşturduğu Akdeniz servisinde ise $81,4 \mathrm{~cm}$ ve $8,4 \mathrm{~mm}$ bulunmuştur. Bu farklılıklar fidan morfolojisinde bireysel seleksiyon ve taksonun önemini de açıkça vurgulamaktadır. her iki taksonda da fidan boyunun kök boğazı çağına göre daha yüksek varyasyona sahip olduğunu göstermesi fidan boyunun seleksiyon amaçlarına daha uygun olduğunu göstermektedir. Uygulanan varyans analizi sonucunda fidan boyu ve kök boğazı çapı bakımından taksonlar arası anlamlı $(p \leq 0.05)$ fark ortaya çıkmıştır. Çalışmaya konu taksonlarda fidan boyu ile kök boğazı arasındaki istatistiksel bakımdan anlamlı $(p \leq 0.05)$ pozitif ilişkiler belirlenmiştir.

Taksonlarda fidanların tamamının Türk Standartları Enstitüsü kalite sınıflarına göre gerek fidan boyu ve gerekse kök boğazı çapı bakımından kaliteli fidan sınıfında yer aldığı ve bu nedenle TSE kalite sınıflarının başarı durumu ayırma analizi ile denetlenemediği ortaya çıkmıştır. Dallı servide, en yüksek dikime elverişsiz fidanların fidan boyu ve kök boğazı çapının birlikte değerlendirildiği kalite sınıflarında (\%36 ve \%26,7) olduğu ve fidan kalitesi bakımından fidanların kök boğazı çapı bakımından fidan boyuna oranla daha iyi bir gelişim performansı yaptığı ortaya çıkmıştır. Uygulanan ayırma analizi sonucunda ise yeni oluşturulan kalite sınıflarının, \%82-\%98 arasında değişen oranlarda başarılı olduğu belirlenmiştir. Piramit servide fidanların yeni kalite sınıflarına dağılımına göre gerek takson ve gerekse tür bazında, dikime elverişsiz fidanların fidan boyu ve kök boğazı çapının birlikte değerlendirildiği kalite sınıflarında (\%42,7 ve $\% 52,7)$ yer aldığı ortaya çıkmıştır. Piramit servide uygulanan ayırma analizi sonucunda yeni oluşturulan kalite sınıflarının, \%80,0- \%96,7 arasında değişen oranlarda başarılı olduğu görülmektedir. Başarı oranlarında fidan boyu ve kök boğazı çapı kombinasyonunun diğer kriterlere oranla başarı durumunun daha düşük belirlenmiştir. Bu sonuçlar, fidan kalitesinde kullanılacak kalite kriterinin önemini de açıkça göstermektedir.

Dallı servi fidanlarının aksine Piramit servi fidanlarında, fidan kalitesi bakımından fidanların boy bakımından çapa oranla daha iyi bir gelişim performansı yaptığı görülmektedir. Çalışmaya konu taksonlardan Dallı servi ve Piramit servinin birlikte yani Akdeniz servisi olarak değerlendirilmesi sonucunda fidanların fidan boyu için \%29'unun, kök boğazı çapı için \%21'nin, fidan boyu ve kök boğazı çapı birlikteliği içinse \%39,7'sinin dikime elverişsiz fidan sınıfında yer aldığı belirlenmiştir. Oluşturulan bu yeni kalite sınıflarının, ayırma analizi ile denetlenmesi sonucunda kalite sınıfının fidan boyu için $\% 89,3$, kök boğazı çapı için \%94,7, fidan boyu ve kök boğazı çapı birlikteliği içinse \%82 oranında başarılı olduğu ortaya çıkmıştır. Bu sonuçlar fidan kalite sınıfının takson bazında oluşturulmasının önemini bir kez daha vurgulamaktadır. Ön çalışma niteliğinde oluşturulan bu kalite sınıfları arazi performansı ile birlikte değerlendirilmelidir. Bu sonuçlar fidan morfolojisi ve kalitesi üzerine etkili olan çevresel ve genetiksel faktörlerin önemini bir kez daha 
vurguladığı gibi, TSE filan kalite sınıfında esas alınan minimum 2 mm kök boğazı çapı kriterinin değiştirilmesi gerektiğinin aciliyetini de bir kez daha göstermektedir.

\section{KAYNAKLAR}

Anonim (1988). Iğne Yapraklı Ağaç Fidanları, TS 2265/Şubat1988. Türk Standartları Enstitüsü yayınları, Türk Standartları Enstitüsü Basımevi.

Anonim (2015). Orman Varlığımız. T.C. Çevre ve Orman Bakanlığı Orman Genel Müdürlüğü Yayınları, Orman Genel Müdürlüğü Basımevi.

Anşin, R., Özkan, Z.C. (1993). Tohumlu Bitkiler. Karadeniz Teknik Üniversitesi Orman Fakültesi Yayınları, Karadeniz Teknik Üniversitesi Basımevi.

Atasoy, H. (1986). Fidanlık Yükseltisinin Doğu Ladini Fidan Morfolojisine Etkisi. Ormancılık Araştırma Enstitüsü Dergisi, 32:125-144.

Bilir, N. (1997). Doğu Karadeniz Bölgesi'nde Toros Sediri (Cedrus libani A.Rich.) Orijin Denemeleri Fidanlık Aşaması. Karadeniz Teknik Üniversitesi Fen Bilimleri Enstitüsü, Yüksek Lisans Tezi.

Bilir, N. (2019). Kızılçam'da (Pinus brutia Ten.) Fidan Kalitesi. Mehmet Akif Ersoy Üniversitesi Fen Bilimleri Enstitüsü Dergisi, 10: 95-101.

Bilir, N., Kaya, C., Ulusan, M.D. (2010). Aydın Orijinli Fıstıkçamı (Pinus pinea L.) Fidanlarında Morfolojik Özellikler ve Fidan Kalitesi. Kastamonu Orman Fakültesi Dergisi, 10:3743.

Çetinkaya, D., Bilir, N. (2019). Toros Sediri'nde (Cedrus libani A. Rich.) Fidan Tipi x Fidan Morfolojisi Etkileşimi. Mehmet Akif Ersoy Üniversitesi Fen Bilimleri Enstitüsü Dergisi, 10:28-33.

Dewald, L.E., Feret, P.P. (1987). Changes in Loblolly Pine Root Growth Potential from September to April. Canadian Journal of Forest Research, 17:635-643.

Dilaver, M., Seyedi, N., Bilir, N. (2015). Seedling Quality and Morphology in Seed Sources and Seedling Type of Brutian pine (Pinus brutia Ten.). World Journal of Agricultural Research, 3:83-85.

Eler, Ü., Keskin, S, Örtel, E. (1993). Toros sediri (Cedrus libani A. Rich.) Fidanlarında Kalite Sınıflarının Belirlenmesi Üzerine Araştırmalar. Ormancılık Araşııma Enstitüsü Dergisi, 240:81-105.
Eyüboğlu, A.K., Karadeniz, A. (1987). Doğu Kayınında (Fagus orientalis Lipsky. ) Dikim Anındaki Fidan Boyu ve Çapı ile Üç Yılıı Boy Büyümesi Arasındaki İlişkiler. Ormancılık Araştırma Enstitüsü Teknik Bülten Serisi, 185:5-13.

Gülcü, S., Albayrak, Y., Bilir, N. (2000). Kermes Meşesi (Quercus coccifera L.) Tohumlarında Soğuk Saklama ve Katlama İşlemlerinin Bazı Fidan Özelliklerine Etkileri. II. Ulusal Fidancılık Sempozyumu, s.40, İzmir.

Kayacık, H. (1966). Adi Servi (Cupresus sempervirens L.) nin Türkiye'deki Coğrafi Dağılışı Üzerine Araştırmalar. İstanbul Üniversitesi Orman Fakültesi Dergisi, 16:39-65.

Kızmaz, M. (1993). Karaçam Fidanlarının Kalite Sınıflarının Belirlenmesi Üzerine Araştırmalar. Ormancılık Araştırma Enstitüsü Yayınları, 238:7-36.

Neyişçi, T. (1996). Kolay ve Güç Yanan Bitki Türleri. Orman Mühendisliği Dergisi, 33: 3-9.

Özel, H.B., Yücedağ, C., Bilir, N., Ölmez, Z., Aydınhan, V. (2018). Kızılçamda (Pinus brutia Ten.) Fidan Tiplerinin Morfolojik Karakterlere Etkisi. Bartın University International Journal of Natural and Applied Sciences, 1:43-47.

Parker, V.H., Niejenhuis, A. (1994). Adaptive Variation in Picea mariana from Northwestern Ontario Determined by ShortTerm Common Environment Tests. Canadian Journal of Forest Research, 24:1653-1661.

Sabuncu, R. (2004). Dallı Servide (Cupressus sempervirens L. var. horizontalis) Fidan Büyüme Karakteristikleri Açısından Genetik Çeşitlilik. Batı Akdeniz Ormancılık Araştırma Müdürlüğü, Teknik Bülten No: 22, $28 \mathrm{~s}$.

Sabuncu, R., Çalışkan, S. (2008). Akdeniz Servisi'nin (Cupressus sempervirens L.) Ekolojisi ve Silvikültürü. İstanbul Üniversitesi Orman Fakültesi Dergisi, 58:53-72.

Tebeş, N.T., Seyedi, N., Bilir, N. (2015). Morphological Characteristics and Quality in Black Pine (Pinus nigra Arnold. subsp. pallasiana) Seedlings. International Journal of Latest Science and Technology, 4:7-9.

Üçler, A. Ö., Gülcü, S., Bilir, N. (2000). Anadolu Karaçamı ve Kızılçam'da Tohum Kaynağı-Morfolojik Fidan Kalitesi İlişkileri. II. Ulusal Fidancılık Sempozyumu, s.39, İzmir.

Yılmazer, C., Bilir, N. (2016). Effect of Seedling Type in Morphology and Quality of Brutian Pine (Pinus brutia Ten.) Seedlings. International Journal of Scientific Research in Science and Technology, 2:237-240. 